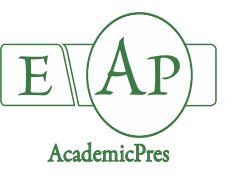

Velickovic I et al. (2021)

Notulae Botanicae Horti Agrobotanici Cluj-Napoca

Volume 49, Issue 1, Article number 12137

DOI: $10.15835 /$ nbha49112137

Research Article

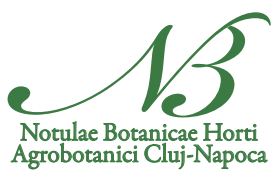

\title{
Prunus spinosa L. leaf extracts: polyphenol profile and bioactivities
}

\author{
Ivona VELIČKOVIĆ' ${ }^{*}, \check{Z ̌ e l j k o ~ Z ̌ I Z ̌ A K} ²^{2}$, Nemanja RAJČEVIĆ ${ }^{1}$ \\ Marija IVANOV ${ }^{3}$, Marina SOKOVIĆ 3 , Petar D. MARIN ${ }^{1}$, \\ Slavica GRUJIĆ ${ }^{1}$
}

\begin{abstract}
${ }^{1}$ University of Belgrade, Faculty of Biology, Institute of Botany and Botanical Garden "Jevremovac", Studentski trg 3, 11000 Belgrade, Serbia; ivona@bio.bg.ac.rs ("correspondingauthor);nemanja@bio.bg.ac.rs; pdmarin@bio.bg.ac.rs; sgrujic@bio.bg.ac.rs 2Institute of Oncology and Radiology of Serbia, Pasterova 14, 11000 Belgrade, Serbia; zizakz@ncrc.ac.rs

${ }^{3}$ University of Belgrade, Institute for Biological Research "Siniša Stankovič"-National Institute of Republic of Serbia, Bulevar DespotaStefana 142,11000 Belgrade, Serbia; marija.smiljkovic@ibiss.bg.ac.rs; mris@ibiss.bg.ac.rs
\end{abstract}

\begin{abstract}
Prunus spinosa leaf extracts in solvents of different polarity (water, ethanol and acetone), their phenol, flavonoid and anthocyanin contents and biological properties were the object of this study. The richest in phenols as well as in flavonoids was acetone extract with $181.19 \mathrm{mg} \mathrm{GAE}$ and $80.10 \mathrm{mg}$ QE per gram of dry extract, respectively. Moreover, the quantity of anthocyanins obtained by HPLC analysis was also the highest in acetone sample. Examined samples possessed antioxidant properties evaluated through four in vitro assays (DPPH, ABTS, FRAP and TRC). The acetone extract was proved to be the best antioxidant among tested samples, which could be ascribed to polyphenols, especially anthocyanins. The aqueous and the ethanol extract exhibited antibacterial effects, being particularly active against $B$. cereus and $E$. cloacae. T. viride, $P$. funiculosum, $P$. ochrochloron, $P$. verrucosum var. cyclopium were the most susceptible among fungal microorganisms examined. Both, the aqueous and the ethanol extract expressed inhibitory activity towards enzymes linked to diabetes mellitus type II. Additionally, the ethanol extract showed significantly higher potential in inhibiting $\alpha$-glucosidase than the drug used as the positive control. Furthermore, the aqueous sample revealed antitumor effects on following malignant cell lines: HeLa, K562 and MDA-MB-453. The results presented herein suggest that $P$. spinosa leaves should be considered as a natural source of bioactive compounds with potential application in phytopharmacy and food industry.
\end{abstract}

Keywords: anthocyanins; antioxidant activity; antitumor activity; enzyme-inhibitory activity; leaf extracts; Prunus spinosa

\section{Introduction}

Plants produce large amounts of phytochemicals with antioxidant abilities to counteract with oxidative stress induced by environmental conditions (Li et al., 2016; Vujanović et al., 2018). Till today, it has been proven that high intake of fruits and vegetables may reduce incidences of serious health disorders caused by oxidative stress, such as neurodegenerative (Tavares et al., 2012), cardiovascular (Kruger et al., 2014), diabetes (He et al., 2019) and cancer (Diaconeasa et al., 2017). Thus, many plant species have been explored for natural 
bioactive compounds that could be implemented in food, pharmacy and cosmetic industry (Cosmulescu et al., 2017). However, wild plant species present easy-accessible, low-cost and rich source of natural bioactive ingredients that is still underexplored and underused.

Genus Prunus consists of numerous economically important species which produce edible fruits, such as plums, cherries, peaches, apricots and almonds (Shi et al., 2013). However, it also counts some wild-growing members, for instance, Prunus spinosa (blackthorn). Blackthorn or "sloe" is perennial shrub distributed in Northern hemisphere, growing on slopes of wide uncultivated areas, along roads and channels, but also in shelterbelts against the wind (Jovanović, 1972). In folk medicine, blackthorn is reputable as astringent, diuretic, purgative, digestive (Fraternale et al., 2009; Barros et al., 2010), mild laxative (Radovanović et al., 2013), antiinflammatory and anti-septic agent (Veličković et al., 2014).

P. spinosa is abundant in bioactive polyphenolic compounds, such as phenolic acids, flavonoids, anthocyanins (Radovanović et al., 2013; Veličković et al., 2014; Pozzo et al., 2019), coumarins, nor-isoprenoid glycosides, A-type proanthocyanidins (Kumarasamy et al., 2004). Many authors proved antioxidant effects of blackthorn extracts (Fraternale et al., 2009; Barros et al., 2010; Pinacho et al., 2015; Tahirović et al., 2018; Popović et al., 2020). Moreover, $P$. spinosa and $P$. padus seed extracts possessed antibacterial properties against some pathogenic bacteria (Kumarasamy et al., 2004). Radovanović et al. (2013) confirmed the antibacterial effects of $P$. spinosa fruit extracts. Besides pathogenic bacteria, $P$. spinosa ethanol fruit extract also affected the growth of examined microfungi (Veličković et al. 2014). Furthermore, $P$. spinosa fruits showed antitumor effects on colorectal cancer cell line (HT29) (Popović et al., 2020). Same authors also showed $\alpha$-amylase and $\alpha$ glucosidase inhibitory properties of blackthorn wild genotypes from Serbia.

Taking into account abovementioned publications it could be noted that Prunus species, particularly their fruits were recently in focus of research. Nevertheless, available literature data indicate that $P$. spinosa leaves have been neglected and/or underexplored. Therefore, this work was designed to complement current knowledge about blackthorn by extracting phenols and flavonoids from leaves with solvents of different polarities (distilled water, $96 \%$ ethanol and acetone). The anthocyanin profile in those extracts was examined and compared. The contribution of polyphenols to antioxidant activity was considered, too. Furthermore, the antibacterial, antifungal, antidiabetic and antitumor activity of aqueous and ethanol extract was determined.

\section{Materials and Methods}

\section{Plant material and extract preparation}

Leaves were collected from a naturally occurring population of $P$. spinosa L. in Croatia (Brdine; N 44.5936; E 15.6467) in July 2015. The voucher specimen was deposited in the Herbarium of Institute of Botany and Botanical Garden "Jevremovac" (Voucher No. 17482). Plant material was air-dried in shade and grounded into a powder prior to extraction. Pulverised plant material was extracted with different solvents (distilled water, $96 \%$ ethanol and acetone) for 24 hours in the dark. The ultrasound was used at the beginning and at the end of extraction for one hour. The extracts were filtered (Whatman filter paper No 1) and the solvents were removed using a rotatory vacuum evaporator (Büchi rotavapor R-114). The obtained dried extracts were kept at $+4^{\circ} \mathrm{C}$ until further use.

\section{Estimation of total phenol and flavonoid contents}

The total phenol content was estimated by their ability to reduce Folin-Ciocalteu reagent (FC) as described by Singleton and Rossi (1965), while the total flavonoid content (TFC) was estimated as previously described by Park et al. (1997). The results were measured spectrophotometrically by Perkin Elmer Lambda Bio UV/VIS spectrophotometer and expressed as mg of gallic acid equivalents (GAE) for TPC and as mg of quercetin equivalents (QE) per g of dry weight (DW) for TFC, respectively. 


\section{HPLC analyses of anthocyanin profile}

To prepare samples of predefined concentration $\left(5 \mathrm{mg} \mathrm{mL}^{-1}\right)$ for HPLC analysis, dry extracts were dissolved in $2 \mathrm{~N} \mathrm{HCl}$ solution in methanol. After 1 hour-incubation in water bath at $90{ }^{\circ} \mathrm{C}$, samples were centrifuged for 15 minutes at $6100 \mathrm{rcf}$. The supernatant was evaporated till dry by rotatory vacuum evaporator $\left(100 \mathrm{mbar}, 40^{\circ} \mathrm{C}\right)$ and redissolved in methanol, filtered through NY filter $0.4 \mu \mathrm{m}$ and injected into HPLC (Thermo HPLC UltiMate 3000 with UV-DAD (UV-Diode Array Detector)). The aliquots of 15 to $30 \mu \mathrm{L}$ (10-100 $\left.\mathrm{mg} \mathrm{mL}^{-1}\right)$ of the sample were injected in triplicate and separated using AcclaimTM PolarAdvantage II $\mathrm{C} 18(\mathrm{~L}=150 \mathrm{~mm}, \mathrm{r}=4.6 \mathrm{~mm}, 3 \mu \mathrm{m})$ column which was kept at constant temperature $\left(30^{\circ} \mathrm{C}\right)$. DAD $(200-600$ $\mathrm{nm}$ ) was used for detection of anthocyanins in samples. The gradient of following solvents: $\mathrm{ddH} 2 \mathrm{O}(\mathrm{A})$, methanol (B) and $1 \%$ formic acid in acetonitrile $(C)$, were used as mobile phase with a flow rate of $1 \mathrm{~mL} \mathrm{~min}^{-1}$. The following protocol was applied: isocratic $0-5 \mathrm{~min}$ ( $\mathrm{A}: \mathrm{B}: \mathrm{C}=90: 0: 10$ ), gradient $5-20 \mathrm{~min}$ (final ratio $A: B: C:=0: 90: 10)$, isocratic $20-25 \mathrm{~min}(A: B: C=0: 90: 10)$. Then, return to initial conditions and isocratic 10 min washout (A:B:C=90:0:10) ensued. The anthocyanins in samples were identified by the comparison of the retention time of unknown peaks with a purchased reference standard (delphinidin, cyanidin, malvidin and pelargonidin) at $525 \mathrm{~nm}$ injected under the same chromatographic conditions and by comparison of UV spectra $(200-600 \mathrm{~nm})$. The anthocyanin contents were calculated from the six-point calibration curve for each of used reference compounds.

\section{Estimation of antioxidant activity}

The antioxidant activity was estimated through DPPH, ABTS, FRAP and TRC in vitro colorimetric assays by Perkin Elmer Lambda Bio UV/VIS spectrophotometer as described in our previous work (Veličković et al., 2020).

\section{Estimation of antimicrobial activity}

Antibacterial and antifungal activity of $P$. spinosa aqueous and ethanol leaf extracts were estimated as suggested by Soković et al. (2010) and Kostić et al. (2017), respectively. For that purposes 8 bacterial (Bacillus cereus (clinical isolate), Micrococcus flavus ATCC10240, Staphylococccus aureus ATCC6538, Listeria monocytogenes NCTC7973, Enterobacter cloacae ATCC35030, Pseudomonas aeruginosa ATCC27853, Salmonella typhimurium ATCC13311, Escherichia coli ATCC35210) and 8 fungal strains (Aspergillus fumigates (human isolate), Aspergillus versicolor (ATCC11730), Aspergillus ochraceus (ATCC12066), Aspergillus niger (ATCC6275), Trichoderma viride (IAM5061), Penicillium funiculosum (ATCC36839), Penicillium ochrochloron (ATCC9112), Penicillium verrucosum var. cyclopium (food isolate) were used.

Determination of antibacterial and antifungal activities was performed in 96 well microtiter plates by serially diluting the samples in Tryptic soy broth and Malt extract broth, respectively. Afterwards, microbial cultures, previously adjusted with sterile saline solution to a concentration of $1 \times 10^{5} \mathrm{CFU} \mathrm{mL}{ }^{-1}$, were added to each well, except negative control. Minimal inhibitory concentrations (MICs), the lowest concentrations that caused visible inhibition of bacterial/fungal growth under a binocular microscope, were determined after 24-hours incubation at $37^{\circ} \mathrm{C}$ for bacteria and after 72 -hours incubation at $28{ }^{\circ} \mathrm{C}$ for microfungi. Minimal bactericidal/fungicidal concentrations (MBC/MFCs) were defined as the lowest concentration without visible bacterial/fungal growth indicating $99.5 \%$ killing of original inocula. $\mathrm{MBC}$ s were determined by re-inoculation of $10 \mu \mathrm{L}$ of samples into sterile broth and further incubation for 24 hours, while MFCs were determined by reinoculation of $2 \mu \mathrm{L}$ of samples into sterile broth and incubation for 72 hours. Ampicillin was used as a positive control for antibacterial and ketoconazole for antifungal activity.

\section{Estimation of enzyme-inhibitory activity}

The $\alpha$-amylase inhibitory activity ( $\alpha$-AIA) was evaluated according to Caraway-Somogyi iodine/potassium method as Zengin et al. (2014) reported. Sample solution $(25 \mu \mathrm{L})$ in different concentrations were mixed with $0.5 \mathrm{mg} \mathrm{mL}^{-1} \alpha$-amylase solution in phosphate buffer $(\mathrm{pH} 6.8$ with $6 \mathrm{mM}$ sodium chloride 
$(\mathrm{NaCl}))$ in a final volume of $75 \mu \mathrm{L}$ in 96 -well microtiter plates and pre-incubated for 15 minutes at $37^{\circ} \mathrm{C}$. Then, $50 \mu \mathrm{L}$ of $0.2 \%$ starch solution in phosphate buffer $(\mathrm{pH} 6.8$ with $6 \mathrm{mM}$ sodium chloride $(\mathrm{NaCl})$ ) was added to initiate the reaction. After 20 minutes of incubation at $37^{\circ} \mathrm{C}$ reaction was stopped by adding $25 \mu \mathrm{L}$ of $1 \mathrm{M}$ hydrochloric acid $(\mathrm{HCl})$. To visualize the reaction, iodine-potassium iodide solution (IKI reagent) was added as colouring agent and absorbance were read at $630 \mathrm{~nm}$ by Multiscan Sky Thermo Scientific Finland Plate Reader. The following Equation 1 was used for calculation of inhibited enzyme (\%):

Percentage of inhibition $(\%)=\left[\left(\Delta \mathrm{A}_{\mathrm{C}}-\Delta \mathrm{A}_{S}\right) \times\left(\Delta \mathrm{A}_{\mathrm{C}}\right)^{-1}\right] \times 100 \%$

where $\Delta \mathrm{A}_{\mathrm{C}}$ represents remainder between control solution (containing all reaction reagents except extract) without and with enzyme solution. Similarly, $\Delta \mathrm{A}_{\mathrm{s}}$ is remainder between sample solutions without and with $\alpha$-amylase.

To estimate $\alpha$-glucosidase inhibitory activity ( $\alpha$-GIA) procedure described by Wan et al. (2013) was used. Briefly, the mixture of sample solution $(120 \mu \mathrm{L})$ and $0.6 \mathrm{U} \mathrm{mL}^{-1} \alpha$-glucosidase solution in $0.1 \mathrm{M}$ phosphate buffer $(\mathrm{pH} 6.8)(20 \mu \mathrm{L})$ was pre-incubated in 96 -well microplates for 15 minutes at $37^{\circ} \mathrm{C}$. The reaction was initiated by adding substrate, $3.5 \mathrm{mM} p$-nitrophenyl- $\alpha$-D-glucopyranoside (PNPG) solution in $0.1 \mathrm{M}$ phosphate buffer ( $\mathrm{pH} 6.8)(20 \mu \mathrm{L})$ and incubation for 20 minutes at $37^{\circ} \mathrm{C} .0 .2 \mathrm{M}$ sodium-carbonate $\left(\mathrm{Na}_{2} \mathrm{CO}_{3}\right)$ was added to the reaction mixture to stop the reaction. Then, absorbances were read at $405 \mathrm{~nm}$ and processed using the same formula (Eq. 1).

The obtained results in both tests were presented through $\mathrm{IC}_{50}\left(\mathrm{mg} \mathrm{mL}^{-1}\right)$ values. Glucobay, officially used drug in the treatment of diabetes mellitus type II, which contains acarbose as active compound, was a positive control.

\section{Estimation of antitumor properties}

\section{Sample preparation}

Stock solutions were prepared by dissolving ethanol crude extract in DMSO and aqueous in distilled water in a final volume of $20 \mathrm{mg} \mathrm{mL}^{-1}$. Samples were obtained by dilution of stock solution in a complete nutrient medium (RPMI-1640 without phenol red) supplemented with $3 \mathrm{mM} \mathrm{L}$-glutamine, $100 \mu \mathrm{g} \mathrm{mL} \mathrm{m}^{-1}$ streptomycin, $100 \mathrm{IU} \mathrm{mL}^{-1}$ penicillin, $10 \%$ heat-inactivated fetal bovine serum (FBS), and $25 \mathrm{mM}$ Hepes and adjusted to $\mathrm{pH} 7.2$ by bicarbonate solution.

\section{Cell culture}

The human cervical carcinoma (HeLa cells), human breast cancer (MDA-MB-453) and human chronic myelogenous leukaemia (K562) malignant cell lines were used for examination of antitumor activity. Examined tumour cell lines were grown in a monolayer at $37^{\circ} \mathrm{C}$ in a humidified air atmosphere with $5 \% \mathrm{CO}_{2}$, except $\mathrm{K} 562$ cells which were cultured in a suspension in the complete nutrient medium. Human embryonic lung fibroblast (MRC-5), a non-cancerous cell line was used as control.

\section{Treatment of cancerous and control cell lines}

Five different concentration of the sample (ranging from 0.125 to $2 \mathrm{mg} / \mathrm{mL}$ ) were added to 96-well microtiter plates where, 20 hours before, Hela (2,500 cells per well), MDA-MB-453 (3,000 cells per well) an MRC-5 (5,000 cells per well) cells were seeded. Two hours prior to the addition of the examined sample, K562 cells were seeded at 5,000 per well to give desired final concentrations within the range mentioned above. Blank was a nutrient medium containing an adequate concentration of extract without seeded cells.

\section{Estimation of cell survival}

The cytotoxic effects of examined samples on malignant and control cell lines were estimated by the microculture tetrazolium test (MTT) described by Mosmann (1983) with modification according to Ohno and Abe (1991). In short, cultures were incubated with examined sample and $5 \mathrm{mg} / \mathrm{mL}$ of 3-(4,5dimethylthiazol-2-yl)-2,5-diphenyltetrazolium bromide in phosphate-buffered saline (MTT dye solution) for 
another 4 hours at $37^{\circ} \mathrm{C}$ in a humidified atmosphere of $5 \% \mathrm{CO}_{2}(\mathrm{v} / \mathrm{v})$. Subsequently, $100 \mu \mathrm{L}$ of $10 \%$ sodium dodecyl sulfate (SDS) was added to visualize the activity of viable cells by extracting insoluble formazan, the product of MTT dye conversion by viable cells. The absorbance was read at $570 \mathrm{~nm}$ after 24 hours and cell survival (S\%) was calculated by the following Equation 2:

$$
\mathrm{S}(\%)=\left(\mathrm{A}_{S} \times \mathrm{A}_{\mathrm{C}}{ }^{-1}\right) \times 100(\%)
$$

where $A_{s}$ and $A_{C}$ represent the absorbance of cells grown in the presence of examined sample and cells grown in nutrient medium only, respectively. The absorbance of blank was subtracted from the corresponding sample incubated with target cells.

The results were expressed through $\mathrm{IC}_{50}$ values which represent the extract concentration that causes a $50 \%$ decrease in the number of survived malignant and normal cells.

\section{Statistical analysis}

The results were obtained from three independent experiments and expressed as their average value $(\mathrm{AV}) \pm$ standard error (SE). Correlations among phenols, flavonoids, anthocyanins and antioxidant activities were presented through Pearsons' coefficient of correlation and interpreted according to Taylor (1990). Results were processed by MS Office Excel 2007.

\section{Results}

The yield of $P$. spinosa leaf extracts ranged from $4.36 \%$ for acetone to $13.65 \%$ for aqueous extract (Table 1). The richest in phenols, as well as in flavonoids was acetone leaf extract with $181.00 \mathrm{mg} \mathrm{GAE} \mathrm{g}^{-1} \mathrm{DW}$ and $80.10 \mathrm{mg} \mathrm{QE} \mathrm{g}^{-1} \mathrm{DW}$, respectively (Table 1 ).

Table 1. Yields (\%), total phenol (TPC) and total flavonoid contents (TFC) in different P. spinosa leaf extracts

\begin{tabular}{|c|c|c|c|}
\hline Sample & Yield $(\%)$ & TPC $\left(\mathrm{mg} \mathrm{GAE} \mathrm{g}^{-1}\right)$ & ${\text { TFC }\left(\mathrm{mg} \mathrm{QE} \mathrm{g}^{-1}\right)}$ \\
\hline Water & 13.65 & $142.40 \pm 3.82$ & $36.28 \pm 0.41$ \\
\hline Ethanol & 9.14 & $116.63 \pm 1.62$ & $45.52 \pm 0.90$ \\
\hline Acetone & 4.36 & $181.19 \pm 1.70$ & $80.10 \pm 0.00$ \\
\hline
\end{tabular}

HPLC analysis enabled the identification and quantification of four basic anthocyanins: delphinidin (Dp), cyanidin (Cy), malvidin (Mv) and pelargonidin (Pg). Similar to TPC and TFC the sum of identified anthocyanins was the highest in acetone extract $\left(4.81 \mathrm{mg} \mathrm{g}^{-1}\right.$ of DW) (Table 2). The cyanidin was dominant anthocyanin compound in all examined samples (Figure 1).

Table 2. The anthocyanin compounds in P. spinosa leaf extracts and their sum (TAC)

\begin{tabular}{|c|c|c|c|c|c|}
\hline Sample & $\mathrm{Dp}\left(\mathrm{mg} \mathrm{g}^{-1}\right)$ & $\mathrm{Cy}\left(\mathrm{mg} \mathrm{g}^{-1}\right)$ & $\mathrm{Mv}\left(\mathrm{mg} \mathrm{g}^{-1}\right)$ & $\mathrm{Pg}\left(\mathrm{mg} \mathrm{g}^{-1}\right)$ & $\mathrm{TAC}\left(\mathrm{mg} \mathrm{g}^{-1}\right)$ \\
\hline Water & 0.07 & 0.74 & 0.27 & 0.05 & 1.13 \\
\hline Ethanol & 0.08 & 1.30 & 0.69 & 0.17 & 2.24 \\
\hline Acetone & 0.08 & 2.78 & 1.46 & 0.49 & 4.81 \\
\hline
\end{tabular}




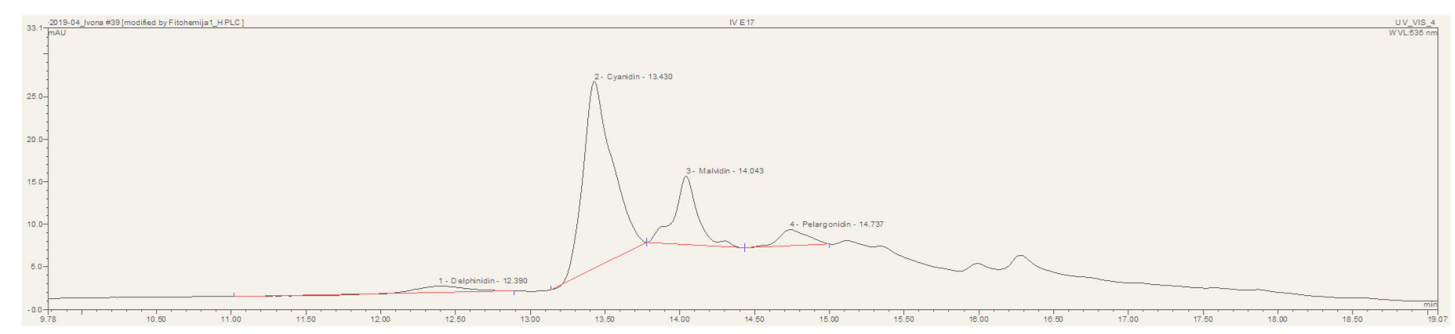

Figure 1. HPLC chromatogram of $P$. spinosa leaf extract

Peak identification: 1) Delphinidin; 2) Cyanidin; 3) Malvidin; 4) Pelargonidin

The acetone extract was the most effective in scavenging DPPH and ABTS free radicals with $\mathrm{EC}_{50}$ values 44.57 and $16.12 \mathrm{mg} \mathrm{mL}^{-1}$, respectively. The values obtained from FRAP assay varied among 0.52 and $0.80 \mu \mathrm{mol}$ $\mathrm{Fe}^{2+}$ equivalents per $\mathrm{g}$ of $\mathrm{DW}$ being the highest for the acetone extract. Additionally, the acetone extract revealed the best antioxidant activity through TRC assays, too (Table 3).

Table 3. Antioxidant activities of $P$. spinosa leaf extracts estimated by four in vitro colorimetric methods

\begin{tabular}{|c|c|c|c|c|}
\hline Sample & DPPH $^{1}$ & ABTS $^{1}$ & FRAP $^{2}$ & TRC $^{1}$ \\
\hline Water & $65.84 \pm 0.64$ & $21.04 \pm 0.53$ & $0.52 \pm 0.01$ & $1,422.00 \pm 3.33$ \\
\hline Ethanol & $57.07 \pm 2.77$ & $22.74 \pm 0.13$ & $0.62 \pm 0.03$ & $1,040.00 \pm 0.38$ \\
\hline Acetone & $44.57 \pm 0.73$ & $16.12 \pm 0.20$ & $0.80 \pm 0.00$ & $633.05 \pm 11.02$ \\
\hline BHA & $5.43 \pm 0.01$ & $\mathrm{NM}$ & $1.83 \pm 0.24$ & $10.97 \pm 0.17$ \\
\hline$L$-ascorbic acid & $3.74 \pm 0.07$ & $2.33 \pm 0.07$ & $6.30 \pm 0.13$ & $8.72 \pm 0.48$ \\
\hline
\end{tabular}

${ }^{1} \mathrm{DPPH}$ and ABTS free radical scavenging antioxidant activities, as well as total reducing capacity (TRC) expressed in terms of EC 50 values $\left(\mu \mathrm{g} \mathrm{mL}^{-1}\right)$; ${ }^{2}$ Ferric Reducing Antioxidant Power expressed in $\mu \mathrm{mol} \mathrm{Fe} \mathrm{F}^{+2}$ equivalents per $\mathrm{g}$ of dry extract; NM not measured

The high positive correlation was found between phenols and flavonoids, phenols and anthocyanins, as well as between flavonoids and anthocyanins (Table 4).

The strong negative correlation was established among phenols, flavonoids and anthocyanins and values obtained for DPPH, ABTS and TRC assays. However, they positively correlated to FRAP values. The values of $r$ obtained for the relation of free radical scavenging assays and TRC values indicated high positive correlation. Nevertheless, FRAP assay strongly negatively correlated with DPPH, ABTS and TRC with $\mathrm{r}$ values $-0.9980,-0.8197$ and -0.9892 , respectively.

Table 4. Correlations between TPC, TFC, antioxidant and antidiabetic properties of $P$. spinosa leaf extracts expressed through Pearson's coefficient of correlation $(r)$

\begin{tabular}{|c|c|c|c|c|c|c|c|}
\hline$R$ & TPC & TFC & TAC & DPPH & ABTS & FRAP & TRC \\
\hline TPC & 1 & & & & & & \\
\hline TFC & 0.8202 & 1 & & & & & \\
\hline TAC & 0.7609 & 0.995 & 1 & & & & \\
\hline DPPH & -0.6746 & -0.9756 & -0.9923 & 1 & & & \\
\hline ABTS & 0.9876 & -0.8999 & -0.8535 & 0.7822 & 1 & & \\
\hline FRAP & 0.7194 & 0.9874 & 0.9981 & -0.9980 & -0.8197 & 1 & \\
\hline TRC & -0.6102 & -0.9537 & -0.9784 & 0.9964 & 0.7272 & 0.9892 & 1 \\
\hline
\end{tabular}

$\mathrm{r} \leq 0.35$ weak correlation; $0.36<\mathrm{r}<0.67$ moderate correlation; $0.68<\mathrm{r}<1$ strong correlation according to Taylor, 1990 
The results of antibacterial activity were presented in Table 5. MIC values varied from 1.42 to $22.73 \mathrm{mg}$ $\mathrm{mL}^{-1}$, while $\mathrm{MBC}$ from 2.84 to $45.45 \mathrm{mg} \mathrm{mL}^{-1}$. The examined samples showed lower inhibitory activity towards tested bacteria than commercial drug ampicillin. The ethanol extract was more efficient against examined pathogenic bacteria, particularly towards E. cloacae and B. cereus.

Table 5. Antibacterial activity of $P$. spinosa leaf extracts determined by microdilution method expressed through MIC/MBC values

\begin{tabular}{|c|c|c|c|c|c|c|}
\hline \multirow[t]{2}{*}{ Sample } & \multicolumn{2}{|c|}{ Water } & \multicolumn{2}{|c|}{ Ethanol } & \multicolumn{2}{|c|}{ Ampicillin } \\
\hline & $\mathrm{MIC}^{1}$ & $\mathrm{MBC}^{2}$ & $\mathrm{MIC}^{1}$ & $\mathrm{MBC}^{2}$ & $\mathrm{MIC}^{1}$ & $\mathrm{MBC}^{2}$ \\
\hline \multicolumn{7}{|c|}{ Test bacterial microorganism } \\
\hline \multicolumn{7}{|c|}{$\mathrm{Gram}^{+}$bacteria } \\
\hline $\begin{array}{l}\text { Bacillus cereus } \\
\text { (clinical isolate) }\end{array}$ & 5.68 & 11.36 & 2.84 & 5.68 & 0.17 & 0.20 \\
\hline $\begin{array}{c}\text { Micrococcus flavus } \\
\text { ATCC } 10240\end{array}$ & 22.73 & 45.45 & 11.36 & 22.73 & 0.13 & 0.15 \\
\hline $\begin{array}{c}\text { Staphylococcus aureus } \\
\text { ATCC } 6538\end{array}$ & 22.73 & 45.45 & 11.36 & 22.73 & 0.10 & 0.20 \\
\hline $\begin{array}{c}\text { Listeria monocytogenes } \\
\text { NCTC7973 }\end{array}$ & 22.73 & 45.45 & 11.36 & 22.73 & 0.20 & 0.33 \\
\hline \multicolumn{7}{|c|}{ Gram-bacteria } \\
\hline $\begin{array}{c}\text { Enterobacter cloacae } \\
\text { ATCC } 35030\end{array}$ & 5.68 & 11.36 & 1.42 & 2.84 & 0.17 & 0.20 \\
\hline $\begin{array}{c}\text { Pseudomonas aeruginosa } \\
\text { ATCC } 27853\end{array}$ & 11.36 & 22.73 & 22.73 & 45.45 & 0.40 & 0.67 \\
\hline $\begin{array}{c}\text { Salmonella typhimurium } \\
\text { ATCC13311 }\end{array}$ & 22.73 & 45.45 & 22.73 & 45.45 & 0.13 & 0.20 \\
\hline $\begin{array}{l}\text { Escherichia coli } \\
\text { ATCC } 35210\end{array}$ & 22.73 & 45.45 & 22.73 & 45.45 & 0.18 & 0.27 \\
\hline
\end{tabular}

${ }^{1,2}$ Minimal inhibitory (MICs) and bactericidal (MBCs) concentrations in $\mathrm{mg} \mathrm{mL}^{-1}$

In the antifungal assay the MIC and MFC values ranged from 2.74 to $23.15 \mathrm{mg} \mathrm{mL}^{-1}$ and from 5.48 to $46.30 \mathrm{mg} \mathrm{mL}^{-1}$, respectively (Table 6). In contrast to antibacterial activity, the aqueous sample showed slightly better antimycotic properties, but still lower than the positive control (ketoconazole). T. viride, P. funiculosum, $P$. ochrochloron were susceptible to both tested extracts, while $A$. ochraceus and $P$. verrucosum var cyclopium were efficiently inhibited by the aqueous extract.

Table 6. Antifungal activity of $P$. spinosa leaf extracts determined by microdilution method expressed through MIC/MFC values

\begin{tabular}{|c|c|c|c|c|c|c|}
\hline \multicolumn{2}{|c|}{ Sample } & \multicolumn{2}{c|}{ Water } & \multicolumn{3}{c|}{ Ketoconazole } \\
\hline \multicolumn{7}{|c|}{ Test fungal microorganism } \\
\hline $\begin{array}{c}\text { Aspergillus fumigatus } \\
\text { (human isolate) }\end{array}$ & 23.15 & 46.30 & 11.57 & 23.15 & 0.23 & 0.67 \\
\hline $\begin{array}{c}\text { Aspergillus versicolor } \\
\text { ATCC11730 }\end{array}$ & 11.06 & 22.12 & 22.12 & 44.25 & 0.20 & 0.47 \\
\hline $\begin{array}{c}\text { Aspergillus ochraceus } \\
\text { ATCC12066 }\end{array}$ & 5.73 & 11.47 & 11.47 & 22.94 & 0.20 & 0.27 \\
\hline $\begin{array}{c}\text { Aspergillus niger } \\
\text { ATCC6275 }\end{array}$ & 11.26 & 22.52 & 22.52 & 45.04 & 0.27 & 0.42 \\
\hline $\begin{array}{c}\text { Trichoderma viride } \\
\text { IAM5061 }\end{array}$ & 2.87 & 5.73 & 5.74 & 11.47 & 0.83 & 2.00 \\
\hline
\end{tabular}


Velickovic I et al. (2021). Not Bot Horti Agrobo 49(1):12137

\begin{tabular}{|c|c|c|c|c|c|c|}
\hline $\begin{array}{c}\text { Penicilliumfuniculosum } \\
\text { ATCC36839 }\end{array}$ & 5.68 & 11.36 & 2.84 & 5.68 & 0.23 & 0.67 \\
\hline $\begin{array}{c}\text { Penicillium ochrochloron } \\
\text { ATCC9112 }\end{array}$ & 5.48 & 10.96 & 2.74 & 5.48 & 1.33 & 1.67 \\
\hline $\begin{array}{c}\text { Penicillium verrucosum } \\
\text { var. cyclopium } \\
\text { (food isolate) }\end{array}$ & 5.58 & 11.16 & 11.16 & 22.32 & 0.27 & 0.40 \\
\hline
\end{tabular}

${ }^{1,2}$ Minimal inhibitory (MICs) and bactericidal (MFCs) concentrations in $\mathrm{mg} \mathrm{mL}^{-1}$

The enzyme-inhibitory activity was evaluated through the ability of extracts to inhibit $\alpha$-amylase and $\alpha$ glucosidase, diabetes-linked enzymes and results were shown in Table 7. Both extracts were more potent inhibitors of $\alpha$-glucosidase. Furthermore, the ethanol sample revealed $\alpha$-glucosidase inhibitory activity ( $\alpha$-GIA) importantly higher even than Glucobay, officially used medicine in the treatment of diabetes mellitus type II.

Table 7. In vitro evaluation of enzyme-inhibitory and antitumor activity of $P$. spinosa leaf extracts

\begin{tabular}{|c|c|c|c|c|c|c|}
\hline \multirow{7}{*}{} & \multicolumn{2}{|c|}{ Enzyme-inhibitory activity } & \multicolumn{5}{c|}{ Antitumor activity } \\
\cline { 2 - 7 } & $\alpha$-AIA & $\alpha$-GIA & HeLa $^{2}$ & K562 & MDA-MB-453 & MRC-5 $^{3}$ \\
\hline \multicolumn{7}{|c|}{ Sample } \\
\hline Water & $81.98 \pm 1.73$ & $2.95 \pm 0.00$ & $770.00 \pm 4.24$ & $865.00 \pm 9.90$ & $877.00 \pm 39.60$ & $1,244.00 \pm 43.84$ \\
\hline Ethanol & $10.86 \pm 0.08$ & $0.03 \pm 0.01$ & $>2,000$ & $>2,000$ & $>2,000$ & $>2,000$ \\
\hline Glucobay & $\mathbf{0 . 2 0} \pm 0.01$ & $\mathbf{0 . 2 3} \pm 0.02$ & & & & \\
\hline
\end{tabular}

${ }^{1} \alpha$-Amylase inhibitory activity expressed through $\mathrm{IC}_{50}$ values $\left(\mathrm{mg} \mathrm{mL}^{-1}\right) ;{ }^{2} \alpha$-Glucosidase inhibitory activity expressed through $\mathrm{IC}_{50}$ values $\left(\mathrm{mg} \mathrm{mL}^{-1}\right){ }^{3}$ antitumor activity on HeLa, K562 and MDA-MB-453 human carcinoma cell lines and MRC-5 control cell line, expressed through $\mathrm{IC}_{50}\left(\mu \mathrm{g} \mathrm{mL}^{-1}\right)$

The results of antitumor activity presented in Table 7. indicate that the aqueous sample decreased cell survival of HeLa, K562 and MDA-MB-453 tumour cell lines, but also showed selectivity in effects on malignant and healthy cells. On the other hand, the ethanol sample had no antitumor properties.

\section{Discussion}

Extraction conditions and techniques influence on extraction yields, polyphenol profile and bioactivity of extracts. Novel extraction methods including ultrasound-assisted extraction (UAE), which is used in this work, are time-consuming and more efficient in extracting bioactive compounds from solid plant matrixes than older traditionally used techniques (Castro-López et al., 2017). In this work, the almost three times higher yield was found in the aqueous than in the acetone extract (Table 1). The authors who previously examined extraction yields of Prunus spp. reported slightly higher yields of the ethanol than the aqueous leaf extract which could be ascribed to the differences among used extraction procedures (Sahan et al., 2011). Despite the lowest yield, the acetone extract was the richest in phenols, flavonoids and anthocyanins. Earlier, several authors quantified phenols in $P$. spinosa fruits and found a few times lower values than those presented herein (Radovanović et al., 2013; Veličković et al., 2014; Popović et al., 2020). This is probably due to the differences among plant organs used for extraction. On the other hand, Park et al. (2012) examined phenol content in different organs of Prunus spp. and for leaf extract found values close to the ones determined in this study (121.41 $\mathrm{mg} \mathrm{GAE} \mathrm{g}^{-1} \mathrm{DW}$ ). Moreover, results for TPC for Prunus spp. leaf extract reported by Karabegović et al. (2014) varied from 85 to $119.4 \mathrm{mg} \mathrm{GAE} \mathrm{g}^{-1} \mathrm{DW}$. In the same work, TFC values were in accordance with our results. Furthermore, Pinacho et al. (2015), evaluated TPC and TFC extracted from $P$. spinosa branches, leaves and fruits using dichloromethane, ethyl-acetate, ethanol and water extract. The results for leaf extract demonstrated in their work ranged from 38.57 to $228.56 \mathrm{mg} \mathrm{GAE} \mathrm{g}^{-1} \mathrm{DW}$ for TPC and from $<0.01$ to 196.88 mg RE $\mathrm{g}^{-1} \mathrm{DW}$ for TFC. HPLC analysis of $P$. spinosa leaf extracts enabled the identification of four 
anthocyanin compounds (delphinidin, cyanidin, malvidin and pelargonidin) and quantification of their contents. According to available literature data, there is a lack of information on HPLC analysis of P. spinosa leaf extracts with only a few reports about compounds found in blackthorn fruits, branches or flowers. For example, Mechini et al. (2017) previously reported lower amounts of summarized anthocyanin compounds in blackthorn fruits, while Popović et al. (2020) obtained results congruent with ours. Veličković et al. (2014) performed HPLC analysis of blackthorn fruit extracts and in aqueous extract identified anthocyanin compounds (cyanidin-3-O-glucoside, cyanidin-3-O-rutinoside and peonidin-3-O-glucoside), while in ethanol and ethanol-aqueous extract phenolic acids (neochlorogenic and caffeic acid) and flavonoids (myricetin and quercetin) were also present. Similar results were also reported by Popović et al. (2020), recently. Pinacho et al. (2015) examined polyphenol profile of $P$. spinosa branches before and after in vitro digestion and besides phenolic acids found coumarins, flavonols and proanthocyanidins. Varga et al. (2017) detected phenolic acids and quercetin glycosides in P. spinosa leaves. Additionally, Owczarek et al. (2016) also identified phenolic acids, quercetin and kaempferol glycosides in blackthorn leaves.

The strong positive correlation was established among TPC and TFC/TAC, as well as among TFC and TAC. Similarly, Pinacho et al. (2015) confirmed that main phenol compounds were flavonoids. Moreover, phenols highly correlated with identified anthocyanin compounds in blackthorn fruits from North Serbia (Popović et al., 2020).

The correlations found between phenols, flavonoids and anthocyanins concentrations and values obtained for DPPH, ABTS, FRAP and TRC suggest that polyphenols, particularly anthocyanins are probably major contributors to antioxidant properties of blackthorn leaves. That was previously confirmed by several researchers (Barros et al., 2010; Radovanović et al., 2013; Veličković et al., 2014; Pinacho et al., 2015; Popović et al., 2020). Furthermore, a high correlation among DPPH and FRAP/TRC values indicate that antioxidant compounds found in blackthorn leaf extracts react rather by electron than hydrogen atom transfer mechanism (Popović et al., 2020).

The aqueous and ethanol leaf extracts of $P$. spinosa were active against examined bacterial and fungal strains. The most susceptible bacterial strains were $E$. cloacae and $B$. cereus, while $T$. viride, $P$. funiculosum, $P$. ochrochloron were among the most affected fungal pathogens. According to Kumarasamy et al., (2004), $P$. spinosa methanol extract of seed was effective against Lactobacillus plantarum, S. aureus and Citrobacter freundii. Radovanović et al. (2013) and Veličković et al. (2014) confirmed the antibacterial effects of $P$. spinosa fruits on several bacterial strains including $S$. aureus, E. coli, P. aeruginosa and $M$. flavus. Blackthorn aqueous fruit extract was also active against S. aureus, Streptococcus sp. and Escherichia coli (Gegiu et al., 2015).

According to the available literature data, this is the first report regarding anti-diabetic properties of blackthorn leaf extracts. Presented results indicate that examined samples possessed notable potential in inhibiting $\alpha$-amylase and $\alpha$-glucosidase, enzymes linked with diabetes mellitus type II. It could be also noticed that the ethanol sample $\left(0.03 \mathrm{mg} \mathrm{mL}^{-1}\right)$ exhibited significantly higher $\alpha$-GIA than the positive control $(0.23 \mathrm{mg}$ $\left.\mathrm{mL}^{-1}\right)$. Additionally, results presented herein were congruent with results obtained for blackthorn fruit extracts by Popović et al. (2020).

Furthermore, the antitumor properties of blackthorn leaf extracts have not been examined previously. According to presented results, the ethanol extract showed effects on following malignant human cell lines: HeLa, K562, MDA-MB-453. Similarly, to anti-diabetic properties, some researchers previously confirmed antitumor properties of $P$. spinosa fruit extracts (Karakas et al., 2019; Popović et al., 2020).

\section{Conclusions}

The blackthorn leaf extracts are rich in phenols, flavonoids and anthocyanins which highly correlated with its antioxidant activity. Among the examined extracts the acetone extract was the most potent antioxidant possibly due to the highest content of polyphenol compounds, especially anthocyanins found in this extract. 
The obtained results indicated that the mentioned leaf extracts exhibited antimicrobial, antidiabetic and antitumor effects. It should be noted that the ethanol sample was particularly effective in inhibiting $\alpha$ glucosidase, carbohydrate hydrolysing enzyme, with significantly lower IC50 value than the positive control (Glucobay). Undoubtedly, $P$. spinosa leaves were unduly treated as waste. Rather it should be observed as an easily accessible natural source of bioactive compounds with potential application in food supplementation and phytopharmacy. Thus, further examination of blackthorn anthocyanins and their bioactivities should be performed.

\section{Authors' Contributions}

Investigation: IV, ŽŽ, NR; Methodology: IV, ŽŽ, MI, NR; Supervision: MS, SG; Writing-original draft: IV; Writing-review and editing: PDM, SG; All authors read and approved the final manuscript.

\section{Acknowledgements}

The authors are grateful to the Ministry of Education, Science and Technological Development for financial support through Projects: 451-03-68/2020-14/200178 and 451-03-68/2020-14/200007.

\section{Conflict of Interests}

The authors declare that there are no conflicts of interest related to this article.

\section{References}

Barros L, Carvalho AM, Morais JS, Ferreira IC (2010). Strawberry-tree, blackthorn and rose fruits: Detailed characterisation in nutrients and phytochemicals with antioxidant properties. Food Chemistry 120(1):247-254. https://doi.org/10.1016/j.foodchem.2009.10.016

Benzie IFF, Strain JJ (1996). The ferric reducing ability of plasma (FRAP) as a measure of antioxidant power: The FRAP $\begin{array}{lll}\text { assay. } & \text { Analytical 239:70-76. }\end{array}$ https://www.sciencedirect.com/science/article/abs/pii/S0003269796902924

Blois MS (1958). Antioxidant determination by use of stable free radical. Nature 181:1199-1200. https://doi.org/10.1038/1811199aO

Castro-López C, Ventura-Sobrevilla JM, González-Hernández MD, Rojas R, Ascacio-Valdés JA, Aquilar CN, MartínezÁvila GCG (2017). Impact of extraction techniques on antioxidant capacities and phytochemical composition of polyphenol-rich extracts. Food Chemistry 237:1139-1148. https://doi.org/10.1016/j.foodchem.2017.06.032

Cosmulescu S, Trandafir I, Nour, V (2017). Phenolic acids and flavonoids profile of extracts from edible wild fruit and their antioxidant properties. International Journal of Food Properties 20(12):3124-3134. https://doi.org/10.1080/10942912.2016.1274906

Diaconeasa Z, Ayvaz H, Rugina D, Leopold L, Stanila A, Socaciu C, ... Jefferson A (2017). Melanoma inhibition by anthocyanins is associated with the reduction of oxidative stress biomarkers and changes in mitochondrial membrane potential. Plant Foods for Human Nutrition 72(4):404-410. https://doi.org/10.1007/s11130-0170638-X

Fraternale D, Giamperi L, Bucchini A, Sestili P, Paolillo M, Ricci D (2009). Prunus spinosa fresh fruit juice: antioxidant activity in cell-free and cellular systems. Natural product communications 4(12):1934578X0900401211. https://doi.org/10.1177/1934578X0900401211 
Gegiu G, Branza AD, Bucur L, Grigorian M, Tache T, Badea V (2015). Contributions to antimicrobial and antifungal study of Prunus spinosa L. Farmacia 63(2):275-279. http://www.revistafarmacia.ro/201502/art-18Gegiu_275-279.pdf

He JH, Chen LX, Li H (2019). Progress in the discovery of naturally occurring anti-diabetic drugs and in identification of their molecular targets. Fitoterapia 134:270-289. https://doi.org/10.1016/j.fitote.2019.02.033

Hussain G, Rasul A, Anwar H, Aziz N, Razzaq A, Wei W, ... Li X (2018). Role of plant derived alkaloids and their mechanism in neurodegenerative disorders. International Journal of Biological Sciences 14(3):341-357. https://doi.org/10.7150/ijbs.23247

Jovanović B (1972). Prunus L. In: Tatić B, Josifović M, Stjepanović L, Janković MM, Gajić M, Kojić M, Diklić N (Eds). Flora S.R. Srbije, Vol 4. SANU, Beograd, Srbija pp 179.

Karabegović IT, Stojičević SS, Veličković DT, Todorović ZB, Nikolić NČ, Lazić ML (2014). The effect of different extraction techniques on the composition and antioxidant activity of cherry laurel (Prunus laurocerasus) leaf and fruit extracts. Industrial Crops and Products 54(2014):142-148. https://doi.org/10.1016/j.indcrop.2013.12.047

Karakas N, Okur ME, Oztruk I, Ayla S, Karadag AE, Polat DÇ (2019). Antioxidant activity of blackthorn (Prunus spinosa L.) fruit extract and cytotoxic effects on various cancer cell lines. Medeniyet Medical Journal 34:297-304. https://doi.org/10.5222/MMJ.2019.87864

Kostić M, Smiljković M, Petrović J, Glamočlija J, Barros L, Ferreira IC, ... Soković M (2017). Chemical, nutritive composition and a wide range of bioactive properties of honey mushroom Armillaria mellea (Vahl: Fr.) Kummer. Food \& Function 8(9):3239-3249. https://doi.org/10.1039/C7FO00887B

Kruger MJ, Davies N, Myburgh KH, Lecour S (2014). Proanthocyanidins, anthocyanins and cardiovascular diseases. Food Research International 59:41-52. https://doi.org/10.1016/j.foodres.2014.01.046

Kumarasamy Y, Cox PJ, Jaspars M, Nahar L, Sarker SD (2004). Comparative studies on biological activities of Prunus padus and P. spinosa. Fitoterapia 75(1):77-80. https://doi.org/10.1016/j.fitote.2003.08.011

Lee S, Jun W (2001). A phylogenetic analysis of Prunus and the Amygdaloideae (Rosaceae) using ITS sequences of nuclear ribosomal DNA. American Journal of Botany 88(1):150-160. https://doi.org/10.2307/2657135

Li H, Tsao R, Deng Z (2012). Factors affecting antioxidant potential and health benefits of plant foods. Canadian Journal of Plant Science 92:1101-1111. https://doi.org/10.4141/cjps2011-239

Meschini S, Pellegrini E, Condello M, Occhionero G, Delfine S, Condello G, Mastrodonato F (2017). Cytotoxic and apoptotic activities of Prunus spinosa Trigno ecotype extract on human cancer cells. Molecules 22(9):1578. https://doi.org/10.3390/molecules22091578

Miller N, Rice-Evans C (1997). Factors influencing the antioxidant activity determined by the ABTS radical cation assay. Free Radical Research 26:195-199. https://doi.org/10.3109/10715769709097799

Mosmann T (1983). Rapid colorimetric assay for cellular growth and survival: application to proliferation and cytotoxicity assays. Journal of Immunological Methods 65:55-63.

Ohno M, Abe T (1991). Rapid colorimetric assay for the quantification of leukemia inhibitory factor (LIF) and interleukin-6 (IL-6). Journal of Immunological Methods 145:199-203. https://doi.org/10.1016/0022$1759(91) 90327-C$

Owczarek A, Magiera A, Matczak M, Piotrowska DG, Olszewska MA, Marchelak A (2016). Optimisation of preparative HPLC separation of four isomeric kaemferol diglycosides from Prunus spinosa L. by application of the response surface methodology. Phytochemistry Letters 20:415-424. https://doi.org/10.1016/j.phytol.2017.01.010

Oyaizu M (1986). Studies on product of browning reaction prepared from glucose amine. Japanese Journal of Nutrition 44:307-315. https://doi.org/10.5264/eiyogakuzashi.44.307

Park JW, Yuk HG, Lee SC (2012). Antioxidant and tyrosinase inhibitory activities of different parts of oriental cherry (Prunus serrulata var spontonea). Food Science and Biotechnology 21(2):339-343. https://doi.org/10.1007/s10068-012-0045-X

Park K, Koo MH, Ikegaki M, Contado JLM (1997). Comparison of the flavonoid aglycone contents of Apis melifera propolis from various regions of Brazil. Arquivos de Biologia e Tecnologia 40(1):97-106.

Pinacho R, Cavero RY, Astiasarán I, Ansorena D, Calvo MI (2015). Phenolic compounds of blackthorn (Prunus spinosa L.) and influence of in vitro digestion on their antioxidant capacity. Journal of Functional Foods 19:49-62. https://doi.org/10.1016/j.jff.2015.09.015 
Popović BM, Blagojević B, Pavlović RŽ, Mićić N, Bijelić S, Bogdanović B, ... Serra AT (2020). Comparison between polyphenol profile and bioactive response in blackthorn (Prunus spinosa L.) genotypes from north Serbia-from raw data to PCA analysis. Food Chemistry 302:125373. https://doi.org/10.1016/j.foodchem.2019.125373

Radovanović BC, Anđelković SM, Radovanović AB, Anđelković MZ (2013). Antioxidant and antimicrobial activity of polyphenol extracts from wild berry fruits grown in southeast Serbia. Tropical Journal of Pharmaceutical Research 12(5):813-819. http://dx.doi.org/10.4314/tjpr.v12i5.23

Sahan Y (2011). Effect of Prunus laurocerasus L. (cherry laurel) leaf extracts on growth of bread spoilage fungi. Bulgarian Journal of Agricultural Science 17(1):83-92. https://www.cabdirect.org/cabdirect/abstract/20113221549

Shi S, Li J, Sun J, Yu J, Zhou S (2013). Phylogeny and classification of Prunus sensu lato (Rosaceae). Journal of Integrative Plant Biology 55(11):1069-1076. https://doi.org/10.1111/jipb.12095

Singleton VJ, Rossi JA (1965). Colometry of total phenolics with phosphomolybdic-phosphotungstic acid reagents. American Journal of Enology and Viticulture 16:144-158. https://www.ajevonline.org/content/16/3/144

Soković M, Glamočlija J, Marin PD, Brkić D, Van Griensven LJ (2010). Antibacterial effects of the essential oils of commonly consumed medicinal herbs using an in vitro model. Molecules 15(11):7532-7546. https://doi.org/10.3390/molecules 15117532

Tahirovic A, Basic N, Copra-Janicijevic A (2018). Effect of solvents on phenolic compounds extraction and antioxidant activity of Prunus spinosa L. fruits. Glasnik hemicara i tehnologa Bosne i Hercegovine (50):19-24. http://www.pmf.unsa.ba/hemija/glasnik/files/Issue\%2050/5-19-24-Tahirovi_A.pdf

Tavares L, Figueira I, Macedo D, McDougall GJ, Leitão MC, Vieira HLA, ... Santos CN (2012). Neuroprotective effect of blackberry (Rubus sp.) polyphenols is potentiated after simulated gastrointestinal digestion. Food Chemistry 131:1443-1452. https://doi.org/10.1016/j.foodchem.2011.10.025

Taylor R (1990). Interpretation of the correlation coefficient: a basic review. Journal of Diagnostic Medical Sonography 6(1):35-39. https://doi.org/10.1177/875647939000600106

Varga E, Domokos E, Fogarasi E, Steanesu R, Fülöp I, Croitoru MD, Laszkó-Zöld E (2017). Polyphenolic compounds analysis and antioxidant activity in fruits of Prunus spinosa L. Acta Pharmaceutica Hungarica 87(1):19-25. https://pubmed.ncbi.nlm.nih.gov/29489094/

Veličković I, Žižak Ž, Rajčević N, Ivanov M, Soković M, Marin P, Grujić S (2019). Examination of the polyphenol content and bioactivities of Prunus spinosa L. fruit extracts. Archives of Biological Sciences 72(1):105-115. https://doi.org/10.2298/ABS191217004V.

Veličković JM, Kostić DA, Stojanović GS, Mitić SS, Mitić MN, Ranđelović SS, Đorđević AS (2014). Phenolic composition, antioxidant and antimicrobial activity of the extracts from Prunus spinosa L. fruit. Hemijska Industrija 68(3):297-303. https://doi.org/10.2298/HEMIND130312054V

Vujanović M, Zengin G, Đurović S, Mašković P, Cvetanović A, Radojković M (2019). Biological activity of extracts of traditional wild medicinal plants from the Balkan Peninsula. South African Journal of Botany 120:213-218. https://doi.org/10.1016/j.sajb.2018.06.012

Wan LS, Min QX, Wang YL, Yue YD, Chen JC (2013). Xanthone glycoside constituents of $S_{\text {wertia }}$ kouitchensis with $\alpha$ glucosidase inhibitory activity. Journal of Natural Products 76(7):1248-1253. https://doi.org/10.1021/np400082g

Zengin G, Sarikurkcu C, Aktumsek A, Ceylan R, Ceylan O (2014). A comprehensive study on phytochemical characterization of Haplophyllum myrtifolium Boiss. endemic to Turkey and its inhibitory potential against key enzymes involved in Alzheimer, skin diseases and type II diabetes. Industrial Crops and Products 53:244-251. https://doi.org/10.1016/j.indcrop.2013.12.043
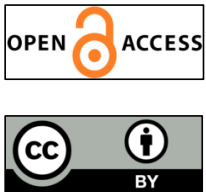

The journal offers free, immediate, and unrestricted access to peer-reviewed research and scholarly work. Users are allowed to read, download, copy, distribute, print, search, or link to the full texts of the articles, or use them for any other lawful purpose, without asking prior permission from the publisher or the author.

License - Articles published in Notulae Botanicae Horti Agrobotanici Cluj-Napoca are Open-Access, distributed under the terms and conditions of the Creative Commons Attribution (CC BY 4.0) License. (c) Articles by the authors; UASVM, Cluj-Napoca, Romania. The journal allows the author(s) to hold the copyright/to retain publishing rights without restriction. 